\title{
EFIKASI TRICHODERMA HARZIANUM DENGAN BERBAGAI BAHAN ORGANIK DALAM PENGENDALIAN PENYAKIT BUSUK PANGKAL BATANG PADA LADA
}

\author{
Cipta Ginting \& Tri Maryono \\ Fakultas Pertanian Universitas Lampung, Jl. Sumantri Brojonegoro No. 1, Bandar Lampung 35145 \\ E-mail:cginting2001@yahoo.com
}

\begin{abstract}
The efficacy of Trichoderma harzianum with various organic matter in controling foot rot of black pepper. The objective of this research was to determine the influence of the kinds of organic matter on the efficacy of Trichoderma harzianum Rifai to control foot rot of black pepper caused by Phytophthora capsici Leonian. Trichoderma spp. were isolated from suppressive and non-suppressive soils taken from black pepper fields with high disease incidence. Screening of Trichoderma spp. isolates was conducted through antagonistic test with dual culture technique. Treatments were arranged in a completely randomized design with six replications. Treatments were rice husk, rice straw, wood dust, Arachis pintoi, mixture of the four organic matters, the mixture without $T$. harzianum, and without organic matter. The test was conducted in greenhouse with media consisted of soil, organic matter, and sand $(2: 2: 1, \mathrm{v} / \mathrm{v})$. After being otoclaved, the medium was infested with $T$. harzianum and $P$. capsici each with five mycelium plugs of $1-\mathrm{cm}$ diameter. Black pepper seedlings were planted 5 days after fungal infestation. After planting the seedlings, five leaf cuts were partly inserted into the soil on each pot. The variables observed were disease incidence on the leaf cuts inserted into the soil and disease severity on the stems and roots. The results show that all 16 Trichoderma isolates inhibited $P$. capsici colonies and some isolates showed stronger inhibition than the others. T. harzianum reduced disease severity, but there was no effect of the kinds of organic matter on the ability of $T$. harzianum to control foot rot.
\end{abstract}

Key words: Biological control, Phytophthora capsici, foot rot of black pepper, Trichoderma

\begin{abstract}
ABSTRAK
Efikasi Trichoderma harzianum dengan berbagai bahan organik dalam pengendalian penyakit busuk pangkal batang pada lada. Penelitian ini bertujuan untuk mengetahui pengaruh jenis bahan organik terhadap efikasi Trichoderma harzianum Rifai untuk mengendalikan penyakit busuk pangkal batang pada lada yang disebabkan oleh Phytophthora capsici Leonian. Trichoderma spp. diisolasi dari tanah yang diduga supresif dan tidak supresif yang diambil dari kebun lada yang tinggi keterjadian penyakitnya. Selanjutnya, skrining isolat Trichoderma spp. dilakukan dengan uji antagonisme dengan teknik kultur ganda. Dalam uji efikasi Trichoderma diuji tujuh perlakuan, yaitu sekam padi, jerami, serbuk kayu, Arachis. pintoi, campuran keempat bahan organik tersebut, campuran tanpa T. harzianum, dan tanpa bahan organik. Perlakuan disusun dalam rancangan acak lengkap dengan enam ulangan. Pengujian dilakukan di rumah kaca dengan media tanah, bahan organik, dan pasir (2:2:1, v/v). Setelah diotoklaf, media diinfestasi dengan isolat Trichoderma terpilih dan $P$. capsici masing-masing dengan lima potongan miselium yang dibuat dengan bor gabus berdiameter $1 \mathrm{~cm}$. Bibit lada ditanam 5 hari setelah aplikasi bahan organik dan infestasi jamur. Segera setelah penanaman bibit lada, lima potongan daun lada berbentuk segitiga ditancapkan sebagian ke dalam tanah pada setiap pot. Peubah yang diukur ialah keterjadian penyakit (disease incidence) pada potongan daun lada dan keparahan penyakit (disease severity) pada batang serta akar. Hasil skrining menunjukkan bahwa 16 isolat Trichoderma spp. yang diperoleh dapat menekan pertumbuhan P. capsici secara in vitro. Terdapat perbedaan tingkat penekanan antarisolat dengan isolat T. harzianum yang paling baik. T. harzianum menekan keparahan penyakit, tetapi jenis bahan organik tidak berpengaruh terhadap keparahan penyakit.
\end{abstract}

Kata kunci: Pengendalian hayati, Phytophthora capsici, busuk pangkal batang lada, Trichoderma

\section{PENDAHULUAN}

Penyakit busuk pangkal batang pada lada (BPBL) sering menjadi masalah serius dalam bercocok tanam lada. Penyakit yang terjadi pada akar atau pangkal batang dapat menyebabkan tanaman layu dan mati secara cepat, atau pada aras yang lebih ringan, mengganggu penyerapan dan transportasi air serta unsur hara. Pada daun, penyakit dapat menyebabkan bercak dan busuk serta gugur sebelum waktunya sehingga 
mengganggu fungsi fisiologis daun. Selain itu, BPBL dapat menyebabkan buah menjadi busuk (Manohara $e t$ al., 2005; Semangun, 2000).

Penyakit BPBL disebabkan oleh Phytophthora capsici Leonian (sinonim: P. palmivora var. Piperis). Jamur ini merupakan jamur tular tanah (soilborne) yang dapat hidup dan sintas (survive) di dalam tanah. Menurut Khew dan Kueh (1980 dalam Semangun, 2000), P. capsici dapat hidup dalam tanah sebagai saprofit selama 18 bulan.

Secara teoritis, BPBL dapat dikendalikan dengan berbagai cara. Akan tetapi, dalam kenyataannya penyakit ini sangat sulit untuk dikendalikan jika telah terjadi di suatu kebun. Cara pengendalian dengan aplikasi fungsida sering gagal karena penyakit dapat berkembang dengan cepat jika lingkungan mendukung perkembangan penyakit. Tindakan pengendalian sering terlambat karena umumnya didasarkan pada gejala penyakit seperti layu pada tajuk tanaman padahal infeksi sering sulit dideteksi karena terjadi pada atau di bawah permukaan tanah. Sementara itu, kepadatan propagula Phytophthora sangat berfluktuasi dalam waktu dan ruang (Shea \& Broadbent, 1983).

Pengelolaan BPBL seharusnya dilakukan secara terpadu dengan mengutamakan pencegahan terjadinya penyakit pada kebun yang belum terserang atau menghambat penyebaran penyakit pada kebun yang baru terinfeksi (Manohara et al., 2005; Semangun, 2000). Salah satu cara pengendalian penyakit yang hendaknya digunakan ialah pengendalian biologi (Cook \& Baker, 1983). Dalam hal ini, Trichoderma spp. sangat berpotensi untuk digunakan (Howell et al., 1997). Penelitian tentang Trichoderma sudah banyak dilakukan namun hasilnya di lapangan belum konsisten sehingga agensia hayati ini belum sering dimanfaatkan. Hal ini mungkin karena pengembangan agensia hayati tidak didahului dengan seleksi strain Trichoderma dan aplikasi Trichoderma tidak terintegrasi dengan penggunaan bahan organik.

Dalam pencarian isolat Trichoderma untuk mengendalikan penyakit soilborne seperti BPBL, tanah supresif hendaknya digunakan sebagai sumber agensia hayati, jika tanah tersebut ditemukan pada kebun tanaman. Tanah supresif ialah tanah yang menyebabkan penyakit tanaman tertekan meskipun terdapat patogen yang virulen, tanaman yang rentan, dan lingkungan yang mendukung perkembangan penyakit. Pada tanah supresif, patogen tidak dapat berkembang atau tidak dapat menimbulkan penyakit (Huber \& Schneider, 1982).

Tanah dengan kandungan bahan organik dan aktivitas mikroba yang rendah cenderung bersifat kondusif terhadap perkembangan penyakit akar tanaman
(Abbasi et al., 2002 dan Stone et al., 2004 dalam Hoitink, 2006). Sementara itu, telah sering dilaporkan bahwa kompos yang diaplikasikan pada tanah dapat mengendalikan penyakit yang disebabkan oleh patogen tular tanah terutama Pythium dan Phytophthora (Agrios, 2005; Hoitink et al., 2006). Mekanisme penekanan penyakit tersebut ialah bahwa aplikasi kompos meningkatkan populasi mikroba tanah secara umum termasuk agensia hayati seperti Trichoderma (Agrios, 2005; Noveriza \& Quimio, 2004; Cook \& Baker, 1983; Isroi, 2008). Sebuah penelitian yang dilakukan di Filipina menunjukkan bahwa persentase bahan organik dalam tanah berkorelasi secara signifikan dengan jumlah jamur yang diisolasi dan antagonis yang berpotensi untuk menurunkan intensitas penyakit (Noveriza \& Quimo, 2004). Akan tetapi, penekanan intensitas penyakit akibat aplikasi bahan organik tidak secara konsisten terjadi (Hoitink, 2006). Konsistensi keefektifan bahan organik diharapkan meningkat dengan infestasi agensia hayati. Hoitink (2006) merujuk beberapa hasil penelitian bahwa infestasi agensia hayati menyebabkan lebih terprediksinya pengendalian penyakit. Selain itu, aplikasi agensia hayati untuk mengendalikan patogen harus memperhatikan ekologinya. Agensia hayati tersebut harus dapat hidup pada kondisi ekologis yang sama dengan yang diperlukan patogen (Paulitz \& Belanger, 2001). Bahan organik diharapkan akan memfasilitasi perkembangan agensia hayati sehingga meningkatkan efektifitas Trichoderma dalam mengendalikan $P$. capsici.

Penelitian ini bertujuan untuk mengetahui pengaruh jenis bahan organik terhadap efikasi Trichoderma harzianum Rifai untuk mengendalikan penyakit BPBL.

\section{METODE PENELITIAN}

Penelitian dilaksanakan di Laboratorium Penyakit Tumbuhan dan Rumah Kaca Fakultas Pertanian Universitas Lampung pada Agustus 2009 sampai Februari 2011.

Isolasi Trichoderma dan $P$. capsici. Untuk mendapatkan isolat Trichoderma spp., pertama-tama ditentukan dua kebun lada di Cahaya Negeri (yaitu Kebun Lada 1 dan Kebun Lada 2) yang mempunyai keterjadian (incidence) BPBL cukup tinggi dengan beberapa tanaman yang sehat. Tanah di sekitar tanaman sehat di sekeliling tanaman sakit tersebut diasumsikan sebagai tanah supresif (suppressive soil) (Ginting, 1997). Terok tanah diambil dari tanah supresif (sampel S3, S4, dan S5). Terok tanah juga diambil dari sekitar 
tanaman yang menunjukkan gejala (tanah tidak supresif), yaitu terok S1, S2, dan S6. Selain itu, terok tanah juga diambil dari satu kebun lada di Natar Lampung Selatan. Sebanyak kira-kira $1 \mathrm{~kg}$ terok diambil dari empat arah di sekeliling tanaman tersebut lalu dimasukkan ke dalam kantong plastik dan disimpan dalam termos es selama transportasi ke laboratotium. Di laboratorium, Trchoderma spp. diisolasi dengan teknik pengenceran (Ginting, 1997). Sebanyak $10 \mathrm{~g}$ setara berat kering tanah dimasukkan ke dalam labu erlenmeyer berisi $90 \mathrm{ml}$ akuades steril dan diaduk rata selama 30 menit. Kemudian, $1 \mathrm{ml}$ dari campuran dimasukkan ke dalam labu erlenmeyer berisi $99 \mathrm{ml}$ akuades steril untuk mendapatkan pengenceran $10^{3}$. Dengan cara yang sama diperoleh pengenceran $10^{5}$. Dengan mikropipet, sebanyak $0,25 \mathrm{ml}$ campuran diambil dari pengenceran $10^{3}$ dan $10^{5}$ dan disebarratakan pada permukaan media dalam cawan petri. Media yang digunakan ialah PDA yang ditambahi rose bengal (40 ppm), streptomisin (60 ppm), dan klorampenikol (60 ppm) (media PDA-RSC). Pengamatan terhadap kultur jamur yang tumbuh dilakukan 3-5 hari kemudian. Isolat Trichoderma spp. yang tumbuh pada media PDA-RSC ditransfer ke media PDA-L dan dimurnikan dengan teknik ujung hifa (hyphal tip). Identifikasi ke spesies dilakukan menurut Rifai (1969).

P. capsici diisolasi dari spesimen yang berupa daun lada yang menunjukkan gejala khas penyakit nekrosis dengan tepi bergerigi (fimbriated). Satu spesimen dimasukkan ke dalam satu kantong plastik dan disimpan dalam termos es dalam transportasi ke laboratorium. Di laboratorium spesimen tersebut diproses pada hari berikutnya. Mula-mula daun bergejala tersebut dicuci dengan air keran yang mengalir, lalu direndam dalam larutan sodium hipoklorida $(\mathrm{NaOCl}) 0,5 \%$ selama $1-2$ menit, lalu dibilas dalam air steril dan dikeringkan pada kertas hisap steril. Daun tersebut dipotong-potong sebesar kira-kira 3-5 mm persegi, lalu empat potongan tersebut diletakkan dalam setiap cawan petri berisi PDA yang dicampur dengan asam laktat $(1,4 \mathrm{ml}$ asam laktat $80 \%$ dalam 1 liter media). Selanjutnya, isolat yang tumbuh ditransfer ke media PDA yang baru, dimurnikan dengan teknik ujung hifa, lalu diuji patogenisitasnya pada daun lada segar.

Skrining Isolat Trichoderma spp. Seleksi terhadap semua isolat Trichoderma spp. yang diperloleh dari hasil isolasi dilakukan dengan uji antagonisme dengan teknik kultur ganda (dual culture). Cuplikan miselium (mycelial plugs) kultur P. capsici dan Trichoderma berumur 3-5 hari masing-masing berdiameter $5 \mathrm{~mm}$ diletakkan pada permukaan media PDA. Kedua jenis miselium berjarak $3 \mathrm{~cm}$ dan masing-masing miselium juga berjarak $3 \mathrm{~cm}$ dari tepi cawan. Perlakuan disusun dalam rancangan acak lengkap dengan tiga ulangan. Pengamatan dilakukan setiap hari dengan mengukur jarijari koloni $P$. capsici. Jari-jari ke arah miselium Trichoderma menunjukkan pengaruh perlakuan, sedangkan jari-jari ke arah sebaliknya merupakan kontrol. Penghambatan dihitung dengan menggunakan rumus $\mathrm{P}=[(\mathrm{K}-\mathrm{T}) / \mathrm{K}] \times 100 \%$ dengan $\mathrm{P}=$ penghambatan $P$. capsici (\%), $\mathrm{K}=$ jari-jari koloni $P$. capsici kontrol (arah berlawanan dengan koloni Trichoderma), dan $\mathrm{T}=$ jari-jari koloni $P$. capsici hasil perlakuan (ke arah koloni Trichoderma). Data yang diperoleh diolah secara statistika dengan uji ragam dan dilanjutkan dengan uji jarak berganda Duncan $(\alpha=0,05)$.

Uji Bahan Organik sebagai Starter. Dua jenis bahan organik yang mudah diperoleh diuji untuk mendapatkan media yang mengandung propagula hidup Trichoderma terbanyak dan dengan persistensi paling lama. Pada uji ini ada empat perlakuan, yaitu (1) menir beras, (2) dedak padi kasar, (3) campuran menir beras dan dedak dengan perbandingan $1: 1(\mathrm{v} / \mathrm{v})$, serta (4) campuran keduanya dengan perbandingan $1: 4(\mathrm{v} / \mathrm{v})$. Seratus ml campuran ditaruh dalam plastik tahan otoklaf dan diotoklaf selama 1 jam pada 2 hari berturut-turut. Lima cuplikan miselium Trichoderma berdiameter $1 \mathrm{~cm}$ dimasukkan ke dalam masing-masing campuran dan diinkubasikan selama 10 hari dengan pengadukan setelah tampak pertumbuhan jamur. Isolat Trichoderma yang digunakan ialah isolat E yakni T. harzianum yang menunjukkan daya antagonisme tertinggi pada percobaan seleksi isolat sebelumnya. Setelah itu, biakan dikeringanginkan selama 3 hari. Perlakuan disusun dalam rancangan acak lengkap dengan enam ulangan. Yang menjadi kriteria media starter yang baik ialah kecepatan tumbuh T. harzianum, kepadatan propagula hidup (colony forming unit/cfu) biakan, dan daya tahan propagula hidup. Kecepatan tumbuh $T$. harzianum dinilai secara visual, yakni dengan memperkirakan persentase permukaan media yang terinfestasi T. harzianum. Persentase dianggap 100\% jika semua permukaan media telah ditutupi miselium $T$. harzianum. Data tentang propagula hidup ini diolah secara statistika dengan uji ragam dan dilanjutkan dengan uji jarak berganda Duncan $(\alpha=0,05)$. Untuk mengetahui daya tahan hidup propagula, setiap bulan selama 3 bulan dihitung kepadatan propagula tersebut dengan teknik pengenceran seperti yang dijelaskan di atas.

Efikasi T. harzianum pada Bahan Organik yang Berbeda. Perlakuan yang diuji ialah jenis bahan organik, 
yaitu sekam padi, jerami padi, serbuk kayu, Arachis. pintoi, campuran keempat bahan organik tersebut, campuran tersebut tanpa Trichoderma, dan tanpa bahan organik yakni hanya tanah dan pasir dengan perbandingan $3: 2$ sebagai kontrol. A. pintoi diperoleh dari Kebun Lada 1 Cahaya Negeri. Sebelum digunakan sebagai bahan organik, A. pintoi diletakkan di laboratorium sampai kering, lalu seluruh bagian tumbuhan dipotong-potong sepanjang $1-2 \mathrm{~cm}$. Perlakuan disusun dalam rancangan acak lengkap dengan enam ulangan. Pengujian dilakukan pada pot plastik berdiameter $17 \mathrm{~cm}$ dengan media tanah, bahan organik, dan pasir $(2: 2: 1, \mathrm{v} / \mathrm{v})$. Media ini terlebih dulu diotoklaf selama 1 jam pada 2 hari berturut-turut. Setelah itu, media tersebut diinfestasi dengan lima potongan miselium Trichoderma dan $P$. capsici berdiameter $1 \mathrm{~cm}$. Isolat Trichoderma yang digunakan ialah $T$. harzianum yang paling tinggi daya antagonisnya sesuai dengan hasil percobaan sebelumnya.

Bibit lada ditanam 5 hari setelah aplikasi bahan organik dan infestasi jamur. Untuk memudahkan terjadinya infeksi, batang lada pada permukaan tanah dilukai dengan jarum steril sedalam $1-2 \mathrm{~mm}$ dan panjang $1 \mathrm{~cm}$. Pengamatan dilakukan setiap hari dan sebagai peubah ialah keparahan penyakit dengan menggunakan skor seperti pada Tabel 1. Peubah yang lain ialah gejala nekrotis pada akar yang ditentukan dengan skor seperti pada Tabel 2. Setelah batang atau akar diberi skor, keparahan penyakit dihitung dengan rumus $\mathrm{K}=[(\mathrm{n} \times \mathrm{v}) /(\mathrm{N} \times \mathrm{V})] \times 100 \%$ dengan $\mathrm{K}=$ keparahan penyakit $(\%), \mathrm{n}=$ skor setiap batang atau akar tanaman, $\mathrm{N}=$ jumlah sampel yakni tiga, dan $\mathrm{V}=$ skor tertinggi yakni lima.

Selain peubah yang berupa keparahan penyakit pada batang dan akar, digunakan juga keterjadian penyakit pada daun lada. Daun lada diambil dari tanaman lain dan telah dipotong dengan gunting steril sehingga berbentuk segitiga. Lima potongan daun ditancapkan sebagian ke dalam tanah pada setiap pot sedemikian sehingga dapat diinfeksi oleh patogen di bawah atau pada permukaan tanah. Pengamatan dilakukan setiap hari setelah inokulasi. Peubah yang diukur ialah keterjadian penyakit (disease incidence). Penghitungan keterjadian penyakit dilakukan dengan rumus $\mathrm{P}=\mathrm{n} / \mathrm{N}$ x $100 \%$ dengan $\mathrm{P}=$ keterjadian penyakit $(\%), \mathrm{n}=$ jumlah potongan daun yang menunjukkan gejala, dan $\mathrm{N}=$ jumlah total potongan daun yang diamati yakni 5 .

Data yang diperoleh (keparahan penyakit pada batang dan akar serta keterjadian penyakit pada potongan daun) diolah secara statistika dengan uji ragam dan dilanjutkan dengan uji jarak berganda Duncan $(\alpha=$ $0,05)$.

\section{HASIL DAN PEMBAHASAN}

Isolat Trichoderma spp. dan P. capsici. Pada pengambilan terok tanah yang pertama, propagul hidup jamur dan Trichoderma telah dihitung dari enam sampel

Tabel 1. Skor penyakit yang digunakan untuk mengukur keparahan penyakit pada batang

\begin{tabular}{ccl}
\hline No & Skor Penyakit & \multicolumn{1}{c}{ Gejala $(\mathrm{x})$} \\
\hline 1 & 0 & Tidak ada gejala \\
2 & 1 & Timbul nekrosis sepanjang 0,5 cm atau kurang \\
3 & 2 & $0,5<\mathrm{x} \leq 1 \mathrm{~cm}$, nekrosis tidak melingkari batang \\
4 & 3 & $\mathrm{x}>1 \mathrm{~cm}$, nekrosis tidak melingkari batang \\
5 & 4 & Nekrosis melingkari batang \\
6 & 5 & Tanaman layu atau mati \\
\hline
\end{tabular}

Tabel 2. Skor penyakit yang digunakan untuk mengukur keparahan penyakit pada akar

\begin{tabular}{ccl}
\hline No & Skor Penyakit & Gejala $(\mathrm{x})$ \\
\hline 1 & 0 & Tidak ada gejala \\
2 & 1 & $\mathrm{x}<10 \%$ \\
3 & 2 & $10 \%<\mathrm{x} \leq 25 \%$ \\
4 & 3 & $25 \%<\mathrm{x}<50 \%$ \\
5 & 4 & $50 \%<\mathrm{x}<75 \%$ \\
6 & 5 & $\mathrm{x}>75 \%$ \\
\hline
\end{tabular}


tanah yang diambil dari dua kebun lada di Lampung Utara (Tabel 3). Tampaknya pada kedua kebun, populasi jamur cenderung lebih tinggi pada tanah supresif (terok tanah S3 dan S4) daripada yang terdapat pada tanah tidak supresif (terok tanah S1 dan S2). Hasil ini sejalan dengan laporan sebelumnya (Ginting, 1997) bahwa tanah supresif mengandung populasi jamur yang lebih padat dibandingkan dengan tanah tidak supresif.

Propagul hidup Trichoderma ditemukan pada terok tanah yang diambil dari Kebun Lada 1, sementara Trichoderma tidak diperoleh dari terok tanah dari Kebun Lada 2. Tidak tampak perbedaan populasi Trichoderma pada kedua jenis tanah pada Kebun Lada 1. Jika dilihat dari populasi jamur secara keseluruhan dan populasi Trichoderma, ada indikasi bahwa tanah supresif khususnya pada Kebun Lada 2 tidak disebabkan oleh Trichoderma. Pada Kebun Lada 1 Trichoderma mungkin berperan dalam menyebabkan tanah menjadi supresif meskipun jumlah propagula hidup hampir sama pada kedua jenis tanah tersebut. Mungkin daya antagonis Trichoderma pada tanah supresif lebih tinggi daripada kemampuan Trichoderma pada tanah tidak supresif. Isolat yang diperolah dan telah diidentifikasi didaftarkan Tabel 4. Kultur P. capsici yang diisolasi dari daun bergejala menunjukkan ciri-ciri hifa nirseptat, miselium keputihan, sporangia berbentuk seperti buah pear, dan dapat menimbulkan gejala khas pada daun lada yakni bertepi bergerigi (fimbriated).

Skrining Isolat Trichoderma berdasarkan Daya Antagonisnya. Semua isolat Trichoderma menghambat koloni $P$. capsici. Besarnya penghambatan berbeda-beda $(p<0,05)$ antar-isolat Trichoderma (Gambar 1 dan 2). Isolat yang paling baik dalam menekan pertumbuhan $P$. capsici ialah $T$. harzianum isolat $\mathrm{E}$, yang selanjutnya digunakan dalam uji efikasi. Trichoderma spp. menekan jamur patogen dengan mekanisme kompetisi, parasitisme, dan/atau antibiosis (Cook dan Baker, 1983; Owley \& Windham, 2008). Selain itu, telah dilaporkan bahwa perbedaan strain Trichoderma memberi pengaruh yang berbeda terhadap keefektifan dalam pengendalian penyakit (Hebbar dan Lumsden, tanpa tahun).

Bahan Organik sebagai Starter. Hasil percobaan menunjukkan bahwa kecepatan tumbuh $T$. harzianum berbeda-beda pada berbagai bahan organik, dengan pertumbuhan paling cepat terjadi pada media menir (Gambar 3). Sejalan dengan itu, kepadatan propagul $T$. harzianum tertinggi terjadi pada media menir diikuti dengan media menir dedak dengan perbandingan 1:1 $(\mathrm{v} / \mathrm{v})$ lalu menir dedak dengan perbandingan 1:4 (v/v) (Gambar 4). Hal ini mungkin disebabkan oleh kandungan nutrisi yang terdapat pada menir lebih banyak bila dibandingkan dengan yang terdapat pada dedak padi kasar. Sampai 10 hari setelah infestasi, kepadatan propapagul hidup $T$. harzianum tampaknya tidak berubah secara signifikan.

Efikasi Trichoderma pada Jenis Bahan Organik yang Berbeda. Pengaruh bahan organik terhadap intensitas penyakit BPBL ditentukan berdasarkan

Tabel 3. Propagul hidup jamur dan Trichoderma pada sampel tanah dari kebun lada di Cahaya Negeri Lampung Utara

\begin{tabular}{clcr}
\hline Sampel Tanah & Tipe Tanah & $\begin{array}{c}\text { Populasi Jamur } \\
\text { (cfu/g tanah) }\end{array}$ & $\begin{array}{c}\text { Populasi Trichoderma } \\
\text { (cfu/g tanah) }\end{array}$ \\
\hline Kebun Lada 1 & & \\
\hline S1 & Tidak supresif & 26.000 & 2.000 \\
S2 & Tidak supresif & 23.333 & 667 \\
S3 & Supresif & 39.333 & 1.333 \\
S4 & Supresif & 34.000 & 1.333 \\
\hline Kebun Lada 2 & & & 0 \\
\hline S5 & Supresif & 7.333 & 0 \\
\hline
\end{tabular}

S1 - S6 = terok tanah; S1, S2, dan S6 merupakan terok tanah dari sekitar tanaman lada yang menunjukkan gejala BPBL (tanah tidak supresif), sementara S3, S4, dan S5 dari sekitar tanaman lada yang tidak menunjukkan gejala (tanah supresif). 
Tabel 4. Isolat Trichoderma spp. hasil isolasi dari tanah yang diambil dari tanah supresif di Kebun Lada Cahaya Negeri dan tanah dari Kebun Lada Natar

\begin{tabular}{|c|c|c|}
\hline Kode Isolat & Spesies & W arna Koloni \\
\hline \multicolumn{3}{|c|}{ Kebun Penelitian Cahaya Negeri } \\
\hline A & Trichoderma harzian um & Hijau tua \\
\hline B & Trichoderma viride & Hijau kekuningan \\
\hline $\mathrm{C}$ & Trichoderma harzian um & Hijau tua \\
\hline $\mathrm{D}$ & Trichoderma harzianum & Hijau tua \\
\hline $\mathrm{E}$ & Trichoderma harzian um & Hijau tua \\
\hline \multicolumn{3}{|c|}{ Kebun Penelitian BPTP Natar } \\
\hline $\mathrm{F}$ & Trichoderma viride & Hijau kekuningan \\
\hline G & Trichoderma koningii & Hijau muda \\
\hline $\mathrm{H}$ & Trichoderma harzian um & Hijau tua \\
\hline $\mathrm{I}$ & Trichoderma viride & Hijau kekuningan \\
\hline $\mathrm{J}$ & Trichoderma koningii & Hijau muda \\
\hline K & Trichoderma viride & Hijau kekuningan \\
\hline $\mathrm{L}$ & Trichoderma harzian um & Hijau tua \\
\hline M & Trichoderma viride & Hijau kekuningan \\
\hline $\mathrm{N}$ & Trichoderma viride & Hijau kekuningan \\
\hline $\mathrm{O}$ & Trichoderma koningii & Hijau muda \\
\hline $\mathrm{P}$ & Trichoderma viride & Hijau kekuningan \\
\hline
\end{tabular}

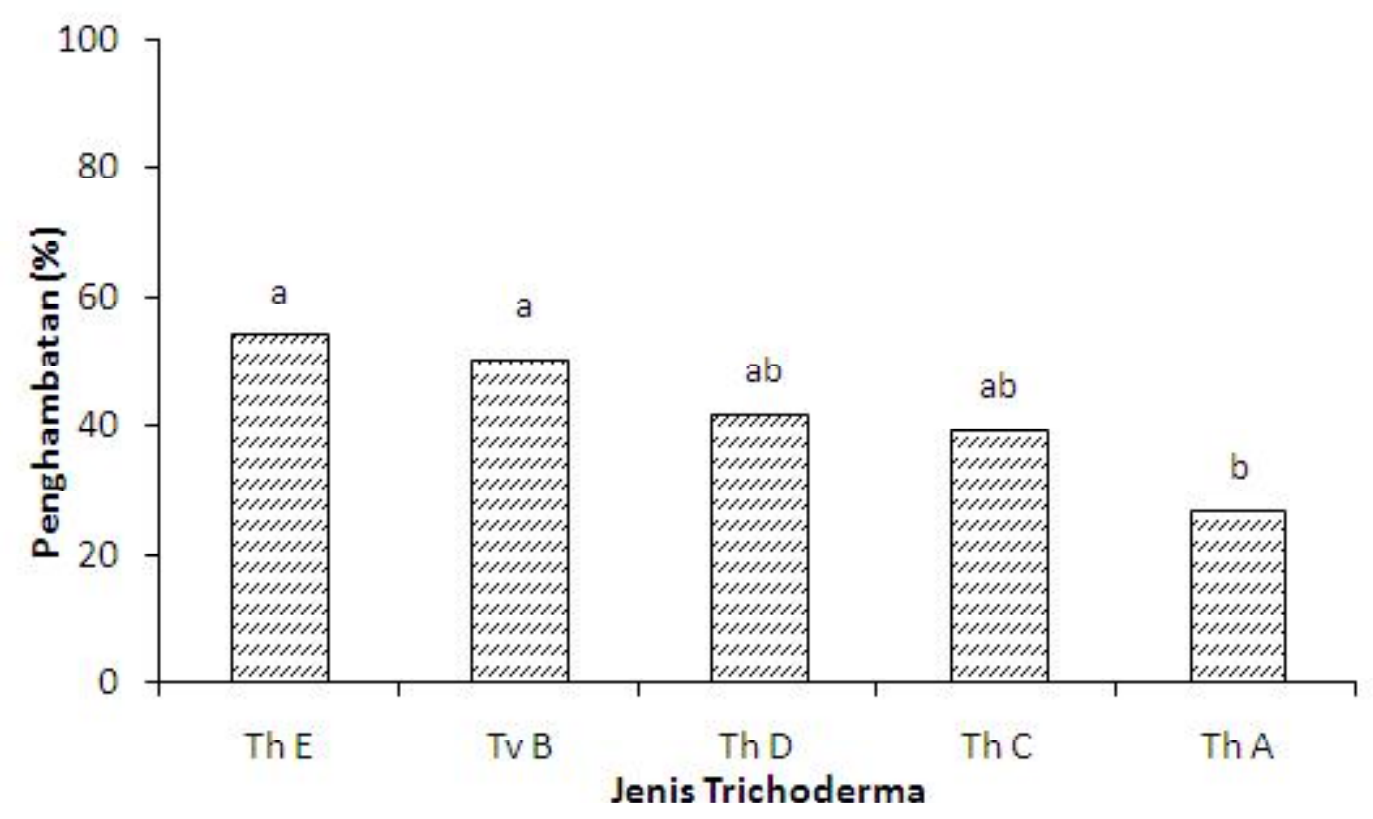

Gambar 1. Penghambatan isolat Trichoderma -spp. dari tanah kebun Percobaan Cahaya Negeri terhadap diameter koloni $P$. capsici $\mathrm{Th}=T$. harzianum, $\mathrm{Tv}=T$. viride, $\mathrm{A}-\mathrm{E}=$ kode isolat. Huruf yang sama di atas bar menunjukkan tidak berbeda nyata menurut uji Duncan $(p>0,05)$. 


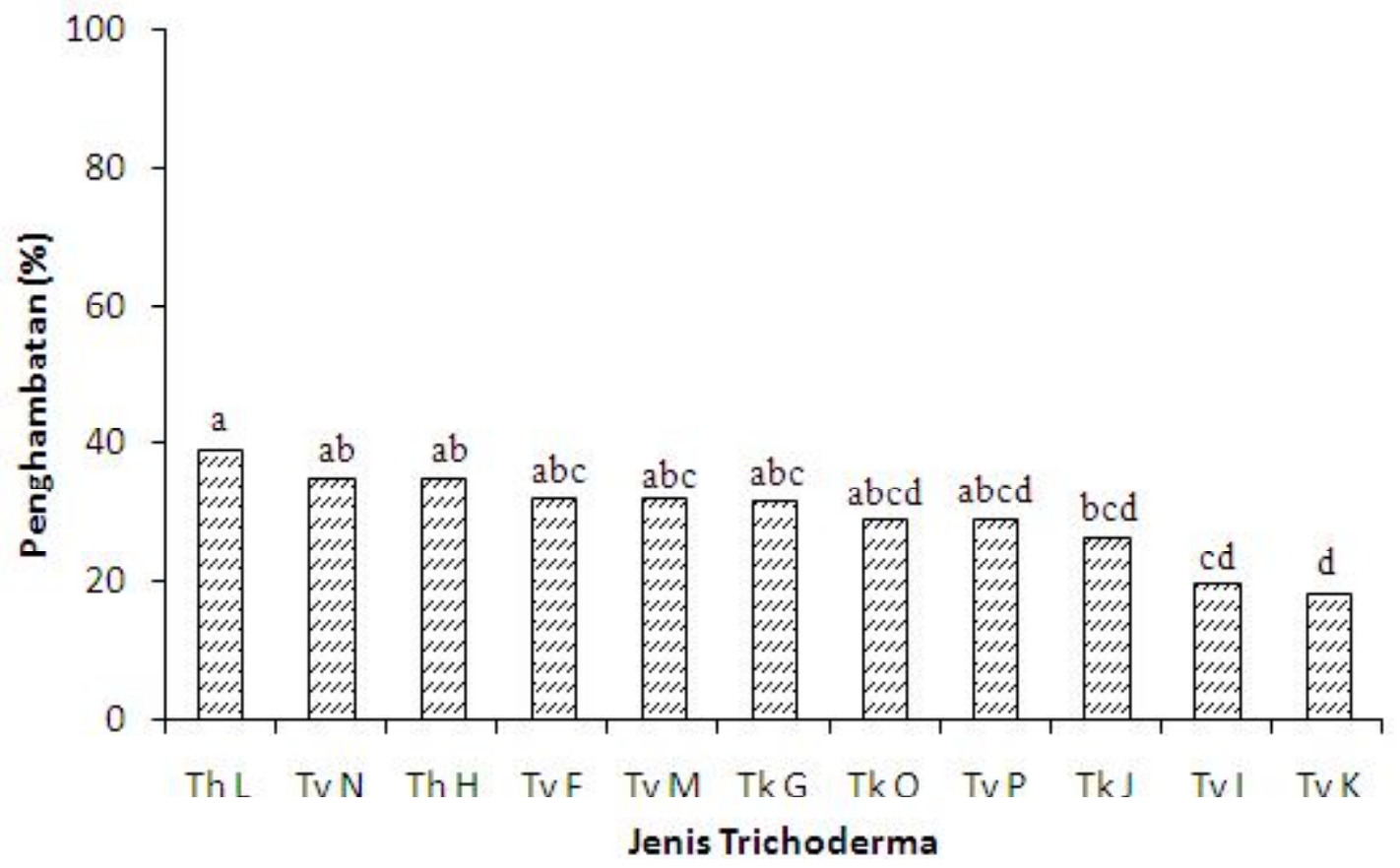

Gambar 2. Penghambatan isolat Trichoderma -spp. dari tanah kebun Percobaan BPTP Natar terhadap diameter koloni $P$. capsici. $\mathrm{Th}=T$. harzianum, $\mathrm{Tv}=T$. viride, $\mathrm{Tk}=T$. koningii) $\mathrm{F}-\mathrm{P}=$ kode isolat. Huruf yang sama di atas bar menunjukan tidak berbeda nyata menurut uji Duncan $(\mathrm{p}>0,05)$.

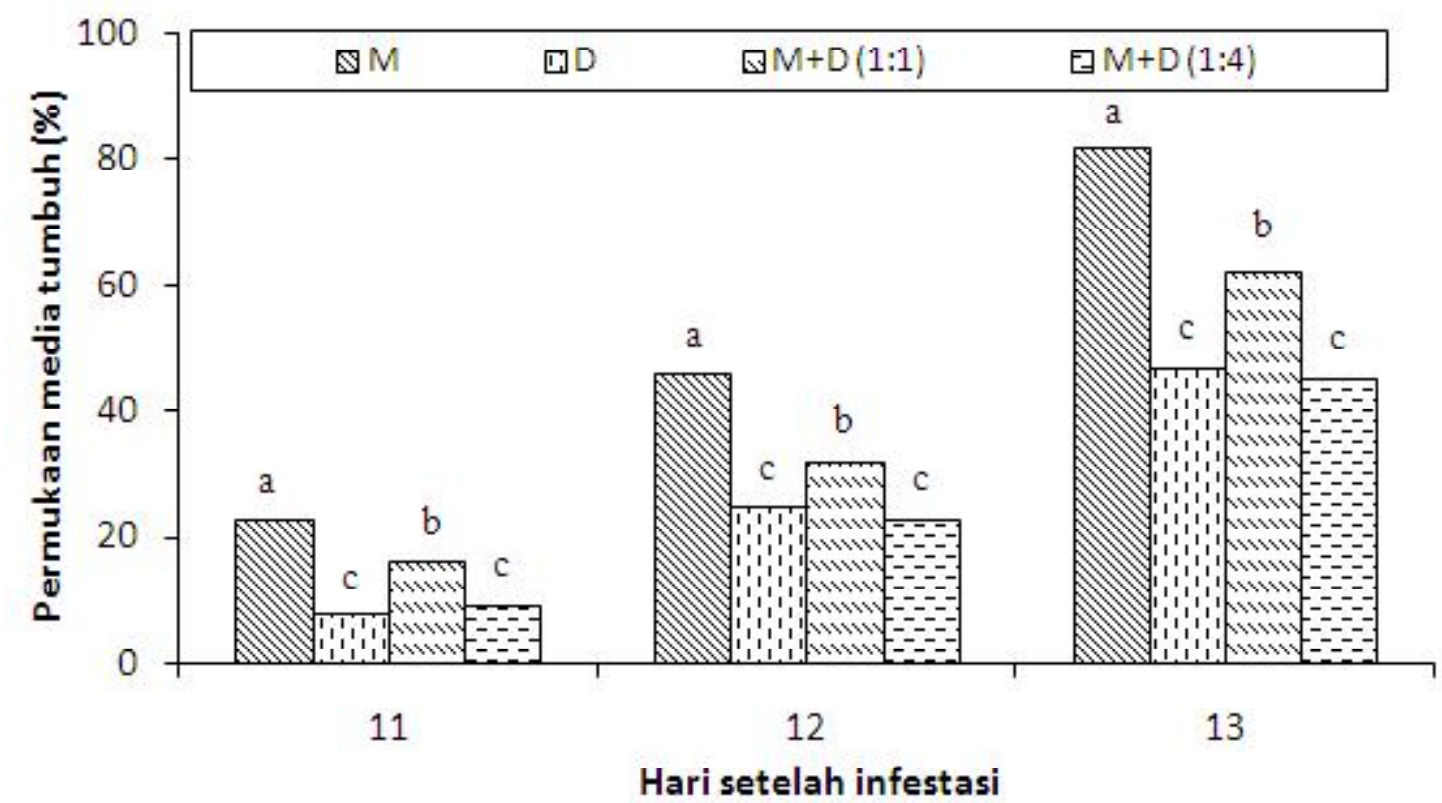

Gambar 3. Persentase permukaan media yang ditumbuhi T. harzianum (isolat E). Huruf yang sama di atas kelompok bar yang sama menunjukkan tidak berbeda nyata menurut uji Duncan $(p>0,05) . \quad M=$ menir dan $D=$ dedak padi kasar. 


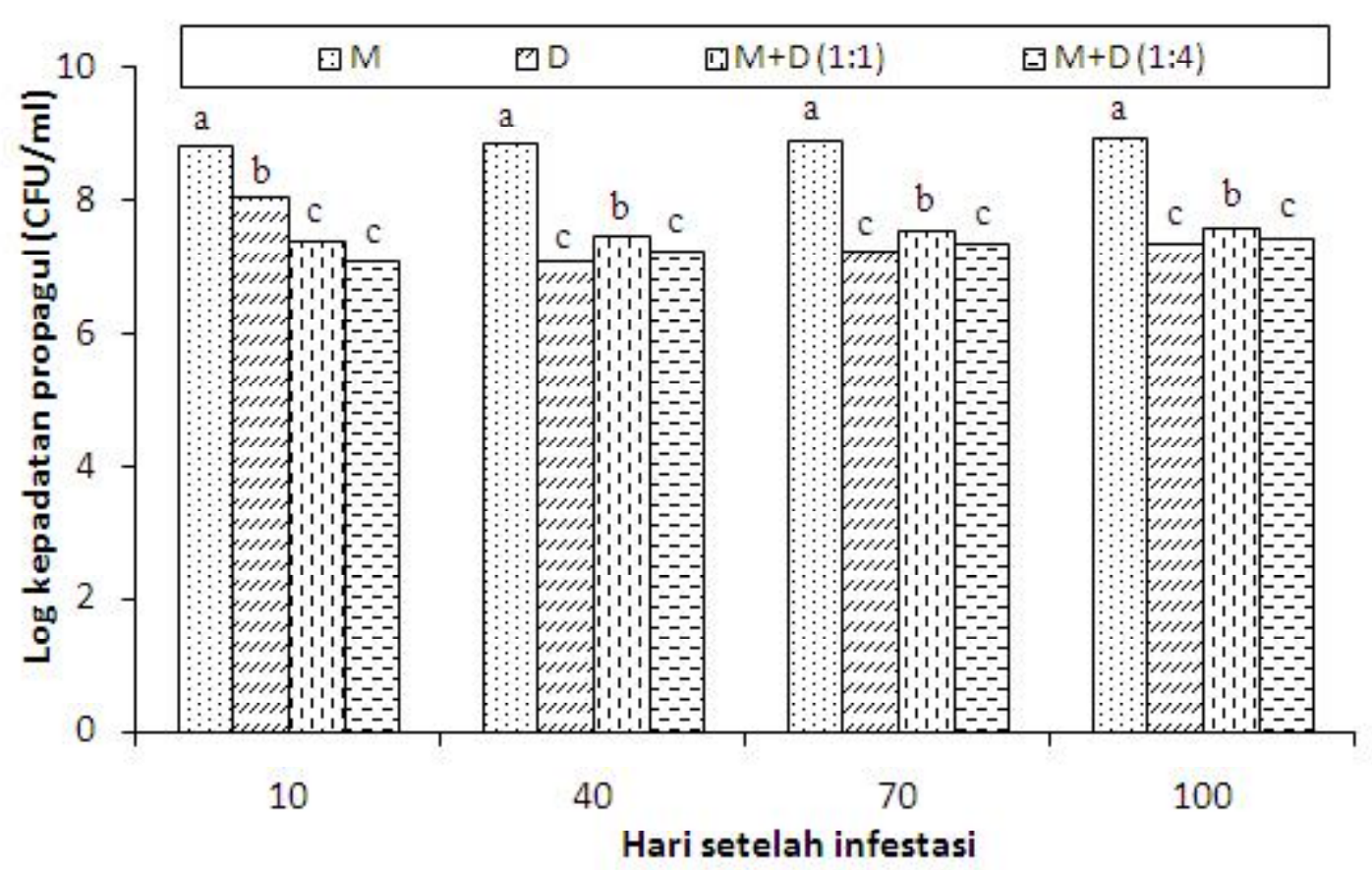

Gambar 4. Kepadatan propagul hidup T. harzianum isolat E 10 - 100 hari setelah infestasi. Huruf yang sama di atas kelompok bar yang sama menunjukkan tidak berbeda nyata menurut uji Duncan $(\mathrm{P}>0,05) . \quad \mathrm{M}=$ menir dan $\mathrm{D}=$ dedak padi kasar.

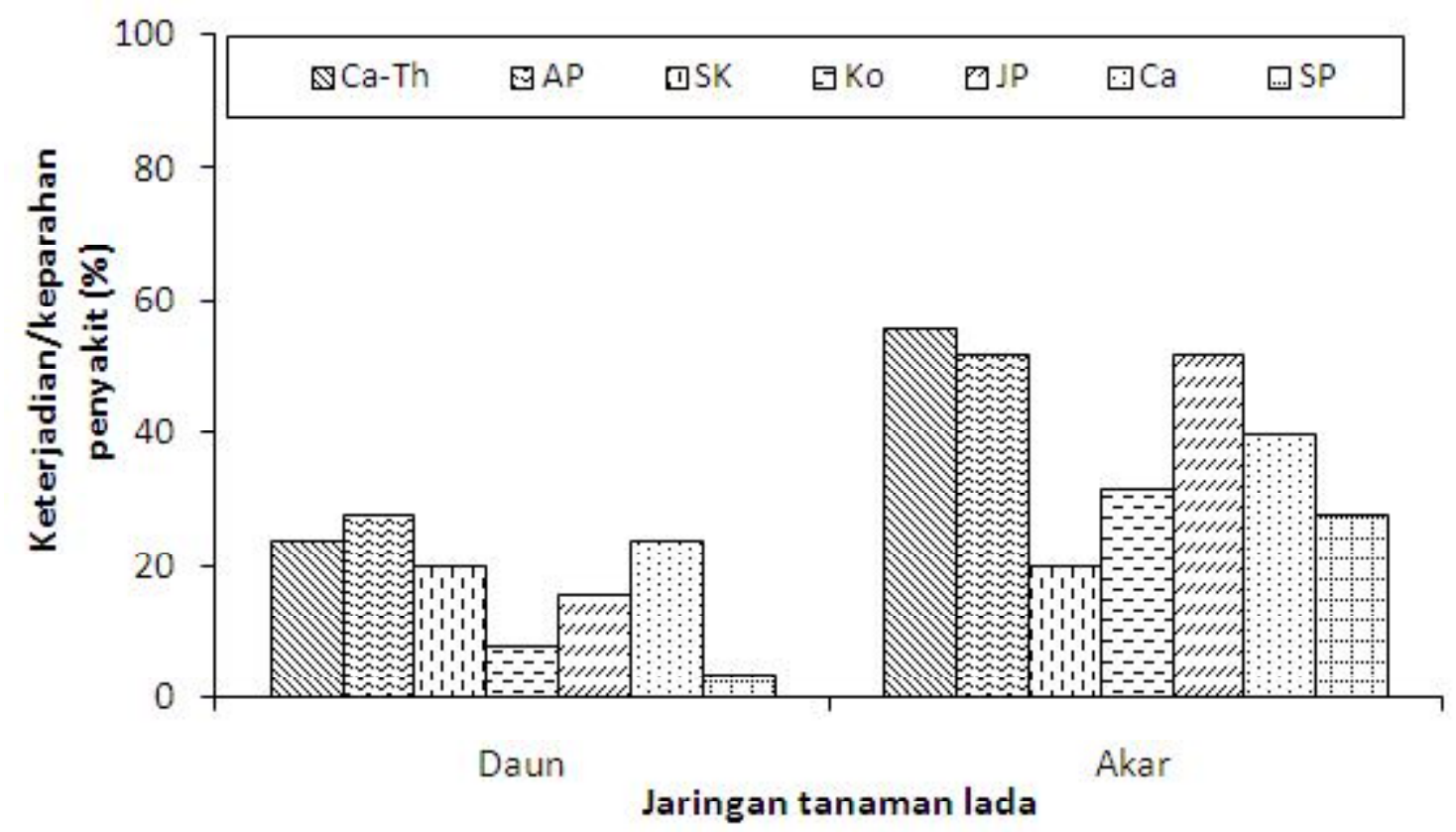

Gambar 5. Keterjadian penyakit pada daun bioindikator dan keparahan penyakit pada akar lada dengan berbagai perlakuan. Perlakuan ialah Ca-Th (campuran keempat bahan organik tanpa T. harzianum, AP (A. pintoi), SK (serbuk kayu), Ko (tanpa bahan organik), JP (jerami padi), Ca (campuran bahan organik), dan SP (sekam padi). Pada masing-masing indikator (daun dan akar), tidak terjadi pengaruh nyata antarperlakuan $(\mathrm{P}>0,05)$. 
keterjadian penyakit pada potongan daun lada, keparahan penyakit pada batang, dan keparahan penyakit pada akar. Hasil pengamatan menunjukkan bahwa bahan organik tidak memberikan pengaruh nyata terhadap keterjadian penyakit pada potongan daun maupun akar yang digunakan sebagai bioindikator (Gambar 5). Pada penggunaan keparahan penyakit pada batang sebagai peubah, respon perlakuan berpengaruh nyata. Gejala penyakit hanya tampak pada batang (dengan keparahan penyakit $8 \%$ ) pada perlakuan campuran bahan organik tanpa T. harzianum. Semua tanaman yang diberi $T$. harzianm tidak menunjukkan gejala (keparahan penyakit 0\%). Data ini menunjukkan keefektifan T. harzianum dalam menekan penyakit, sedangkan bahan organik yang diuji tidak menunjukkan perbedaan pengaruh.

Trichoderma yang diaplikasikan dalam bahan organik memunyai keuntungan yaitu tersedianya nutrisi bagi pertumbuhan Trichoderma sehingga dapat mendukung pertumbuhan Trichoderma. Selain itu, bahan organik berfungsi sebagai tambahan sumber nutrisi bagi tanaman. Hal ini terutama diperlukan pada tanah yang rendah kandungan bahan organik dan nutrisi seperti yang terjadi pada tanah di Lampung. Bahan organik sudah digunakan dalam aplikasi agensia hayati. Misalnya, di India penyakit BPB pada lada dikendalikan secara hayati dengan menggunakan agensia hayati $T$. viride yang dicampur dengan bahan organik. Pada saat tanam, inokulum sebanyak $50 \mathrm{~g}$, yang dicampur dengan $500 \mathrm{~g}$ pupuk kandang, diaplikasikan pada lubang tanam sebelum penanaman bibit. Pada tanaman dewasa, juga sebanyak $50 \mathrm{~g}$, yang dapat dicampur dengan $1 \mathrm{~kg}$ pupuk kandang atau bahan organik lain, diaplikasikan di sekitar pangkal batang dan ditutup dengan tanah (Sahayarani, et al., 2005). Penggunaan bahan organik pada saat aplikasi Trichoderma diharapkan meningkatkan pertumbuhan dan keefektifan Trichoderma. Akan tetapi, pengaruh bahan organik pada percobaan ini tidak tampak pada indikator potongan daun, batang, maupun akar (Gambar 5). Selain itu, keparahan penyakit pada semua perlakuan termasuk pada perlakuan tanpa bahan organik relatif rendah. Oleh karena itu, hasil penelitian ini masih perlu dikonfirmasi dengan melakukan percobaan serupa dan dengan upaya untuk meningkatkan intensitas penyakit sehingga dampak perlakuan dapat dibandingkan dengan lebih jelas.

\section{SIMPULAN}

Dari hasil penelitian ini, dapat disimpulkan bahwa semua isolat Trichoderma spp. menekan perkembangan koloni $P$. capsici in vitro dalam media
PDA. Kandungan menir pada media pertumbuhan meningkatkan kepadatan propagul Trichoderma hidup. T. harzianum menurunkan keparahan penyakit pada batang. Pengaruh jenis bahan organik tidak tampak terhadap efikasi Trichoderma dalam mengendalikan penyakit BPBL pada peubah daun, batang, maupun akar.

\section{SANWACANA}

Pada kesempatan ini disampaikan terima kasih kepada Direktorat Penelitian dan Pengembangan Masyarakat (Dit. Litabmas) yang telah menyediakan dana penelitian. Selain itu, ucapan terima kasih disampaikan kepada Rusdi Evizal yang memberi masukan dalam diskusi tentang tanaman lada dan mahasiswa yang terlibat dari awal sampai akhir penelitian yaitu Dwi Diningsih Adi Putri, Ivayani, dan Aistria Larasati Rais. Selain itu, kami juga berterima kasih kepada teknisi di Laboratorium Penyakit Tumbuhan, yakni Widyaningrum, Paryadi, dan Iwantoro.

\section{DAFTAR PUSTAKA}

Agrios GN. 2005. Plant Pathology. $5^{\text {th }}$ Ed. Elsevier Academic Press, Burlingkton, MA. 922 pp.

Cook RJ \& Baker KF. 1983. The Nature and Practice of Biological Control of Plant Pathogens. The American Phytopathological Society, St. Paul, Minnesota. 539 pp.

Ginting C. 1997. Determination of the occurence of suppressive soil to foot rot in black pepper field. Pros. Kongr. Nas. XIV PFI. Palembang, Oktober 1997. Hlm. 320 - 325.

Hebbar KP \& Lumsden RD. Tanpa tahun. Formulation and fermentation of biocontrol agents of cacao fungal pathogens: example of Trichoderma species. http://www.cabi.commodities.org/Acc/ ACCrc/W-BPD/ch7.pdf. Diakses pada 11 Januari 2006.

Hoitink HAJ, Madden LV \& Dorrance AE. 2006. Systemic resistance induced by Trichoderma spp.: Interactions between the host, the pathogen, the biocontrol agent, and soil organic matter quality. Phytopathology 96:186-189.

Howell CR, DeVay JE, Garber RH, \& Batson WE. 1997. Field control of cotton seedling diseases with Trichoderma virens in combination with fungicide seed treatments. J. of Cotton Science 1:15-20. 
Huber DM \& Schneider RW. 1982. The Description and occurrence of suppressive soils. Pp. 1-8 In: Schneider RW. Suppressive Soils and Plant Disease. The American Phytopathological Society, St. Paul, Minnesota.

Isroi. 2008. Kompos. Makalah Balai Penelitian Bioteknologi Perkebunan Indonesia, Bogor. Dalam http://wikipedia.org/wiki/Kompos. $12 \mathrm{hlm}$. Diakses pada 2 April 2008.

Manohara D, Wahyuno D, \& Noveriza. 2005. Penyakit busuk pangkal batang tanaman lada dan strategi pengendaliannya. Perkembangan Teknologi TRO 17:41-51.

Noveriza R \& Quimio TH. 2004. Soil mycoflora of black pepper rhizosphere in the Philippines and their in vitro antagonism against Phytopthora capsici L. Indonesian J. of Agric. Sci. 5:1-10.

Ownley BH \& Windham MT. 2008. Biological control of plant pathogens. Pp. 423 - 435 in: Trigiano, R.N., Windham, M.T., and Windham, A.S. (Eds.). Plant Pathology: Concept and Laboratory Exercise. CRC Press, Boca Raton, Florida. 558 pp.
Paulitz TC \& Belanger RR. 2001. Biological control in greenhouse systems. Annu. Rev. Phytopathol. 39:103-133.

Rifai MA. 1969. A Revision of the Genus Trichoderma. Mycological Paper 116, 56 pp.

Semangun H. 2000. Penyakit-penyakit Tanaman Perkebunan di Indonesia. Gadjah Mada University Press, Yogyakarta. $835 \mathrm{hlm}$.

Shea SR \& Boadbent P. 1983. Development in cultural and biological control of Phytophthora diseases. Pages 335-350 in: Erwin, D.C., Bartnicki-Garcia, S., and Taso, P.H. Eds. Phytophthora: Its Biology, Taxonomy, Ecology, and Pathology. APS Press, St. Paul, Minnesota.

Sahayarani S, Soundarajan RP, \& Lakshmanan V. 2005. The Hindu, online edition of India's National Newspaper. http://www.hindu.com/seta/2005/09/ 29/stories/200509 2901131700.htm. Diakses pada 12 Februari 2008. 